\title{
Prevalence of depressive symptoms and factors associated in the elderly of the city of Pelotas-RS
}

\section{Prevalência de sintomas depressivos e fatores associados em idosos da cidade de Pelotas-RS}

\section{Prevalencia de síntomas depresivos y factores asociados en ancianos de la ciudad de Pelotas-RS}

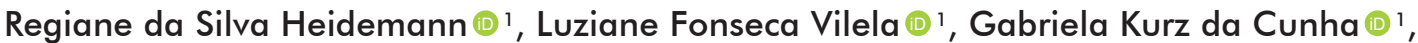 \\ Renan Garcia Caldas (1) ', Pâmela Silva Vitória Salerno (i) ', Isabel Clasen Lorenzet (1) ', \\ Camila Perelló Ferrúa (ㄱ) 1, Mariana Bonati de Matos (1) 1, Gabriele Cordenonzi Ghisleni ${ }^{(1)}$ 1, \\ Rachel Krolow Santos Silva Bast (D2) ${ }^{2}$, Fernanda Nedel ${ }^{1} \square$ \\ 2 Universidade Federal do Rio Grande do Sul (UFRGS). Porto Alegre, RS, Brasil.
}

\section{ARTICLE INFO}

Article history

Received: 14/03/2019

Accepted: 06/06/2019

Published: 29/08/2019

\section{$\triangle$ Correspondent Author}

Fernanda Nedel

Universidade Católica de Pelotas (UCPel)

Programa de Pós-Graduação em

Saúde e Comportamento

Rua Félix da Cunha, 412

96010-901, Pelotas, RS, Brazi

fernanda.nedel@gmail.com

(C) 2019 All rights reserved

\section{Editors}

Alfredo Cataldo Neto

Newton Luiz Terro

Assistant Editors

Paula Engroff

Vanessa Sgnaolin

\begin{abstract}
AIM: The aim of this study was to evaluate the prevalence of depressive symptoms and factors associated in the elderly of the city of Pelotas, southern Brazil.

METHODS: In this cross-sectional study, the variables of interest were investigated with instruments about the socio-economic profile, aspects of physical and professional activities, eating and sleeping habits.

RESULTS: 312 elderly people were interviewed, with a prevalence of depressive symptoms of $30.5 \%$. A higher prevalence of depressive symptoms were found in women, individuals older than 81 years, from the low class, living alone, physically inactive, and retired. In the adjusted analysis, the non-practice of physical activity, low sleep quality, and daily sleeping medication were statistically associated with the outcome. In contradiction to the literature, our results refute the well-established gender roles that preconize that males are more affected by physical impairment, while the females are more affected by psychological and psychiatric disorders.

CONCLUSIONS: In conclusion, it is important to identify the prevalence of depressive symptoms in a population commonly affected by other diseases. In addition, characteristics associated with depression were detected, which can help prevent or improve depression in this age group.
\end{abstract}

KEYWORDS: Depression; Health of the elderly; Quality of life.

\section{RESUMO}

OBJETIVO: O objetivo deste estudo foi avaliar a prevalência de sintomas depressivos e fatores associados em idosos da cidade de Pelotas, sul do Brasil. MÉTODOS: Neste estudo transversal, as variáveis de interesse foram investigadas com instrumentos sobre perfil socioeconômico, aspectos das atividades físicas e profissionais, hábitos alimentares e de sono.

RESULTADOS: Foram entrevistados 312 idosos, com prevalência de sintomas depressivos de 30,5\%. Uma maior prevalência de sintomas depressivos foi encontrada em mulheres, com mais de 81 anos, de baixa classe, vivendo sozinhos, fisicamente inativos e aposentados. Na análise ajustada, a não prática de atividade física, a baixa qualidade do sono e a medicação diária para dormir foram estatisticamente associadas ao desfecho. Em contradição com a literatura, nossos resultados refutam papéis de gênero bem estabelecidos que preconizam que os homens são mais afetados pelo comprometimento físico, enquanto as mulheres são mais afetadas por distúrbios psicológicos e psiquiátricos.

CONCLUSÕES: Em conclusão, é importante identificar a prevalência de sintomas depressivos em uma população comumente afetada por outras doenças. Além disso, características associadas à depressão foram detectadas, o que pode ajudar a prevenir ou melhorar a depressão nessa faixa etária.

DESCRITORES: Depressão; Saúde do idoso; Qualidade de vida. 


\section{RESUMEN}

OBJETIVO: El objetivo de esto estudio fue para evaluar la prevalencia de síntomas depresivos y factores asociados en ancianos de la ciudad de Pelotas, sur de Brasil.

MÉTODOS: En este estudio transversal, las variables de interés fueron investigadas con instrumentos sobre perfil socioeconómico, aspectos de las actividades físicas y profesionales, hábitos alimentarios y de sueño.

RESULTADOS: Fueron entrevistados 312 ancianos, con prevalencia de síntomas depresivos del 30,5\%. Una mayor prevalencia de síntomas depresivos fue encontrada en mujeres, de más de 81 años, de clase baja, viviendo solos, físicamente inactivos y jubilados. En el análisis ajustado, la nula práctica de actividad física, la baja calidad del sueño y la medicación diaria para dormir fueron estadísticamente asociadas al desenlace. En contradicción con la literatura, nuestros resultados refutan papeles de género bien establecidos que preconizan que los hombres son más afectados por el compromiso físico, mientras que las mujeres son más afectadas por disturbios psicológicos y psiquiátricos.

CONCLUSIONES: En conclusión, es importante identificar la prevalencia de síntomas depresivos en una población comúnmente afectada por otras enfermedades. Además, las características asociadas a la depresión se han detectado, lo que puede ayudar a prevenir o mejorar la depresión en este grupo de edad.

Palabras CLAVE: Depresión; Salud del anciano; Calidad de vida.

\section{INTRODUCTION}

Major depressive disorder, also known as depression, has as main characteristics depressed mood, feeling of emptiness or irritability, accompanied by somatic and cognitive changes that significantly compromise the functional capacity of the individual ${ }^{1}$.

In old age, somatic symptoms such as changes in sleep and appetite, loss of pleasure in activities, loss of energy, and ruminations of the past, among others make the diagnosis of depression difficult as symptoms overlap with those of other diseases or common agerelated complaints ${ }^{2}$. Furthermore, the presence of a depressed mood or sadness is not enough for a diagnosis of depression in the elderly, because verbalizing irritability, guilt, helplessness, lack of feelings and emotions, or loss of interest can be difficult in some cases $^{3}$.

Despite the above, over the years, the prevalence of depression in older people has increased (10 to $25 \%)^{4}$ and, according to Ramos et al. (2005), it tends to continue increasing as the aging of the population $(34 \%)^{5}$. Although depression may occur as a one-time episode, it usually becomes a recurrent condition ${ }^{1}$. Thus, elderly people with depression may present biological alterations, which contribute to significant problems, such as loss of autonomy, functional incapacity, low self-esteem, isolationism, negativism, feelings of rejection, devaluation, and even depersonalization as to their role in society ${ }^{2}$.

Therefore, it is of great relevance to know the possible factors that may be associated with depression in this specific population. Campos et al. (2014) and Téllez et al. (2016) evidenced that not practicing physical activity, poor quality of sleep, and the continuous use of sleeping medication may have a strong influence on the onset of the disorder ${ }^{6,7}$. In addition, low income, low social conditions ${ }^{8}$, and health and functional problems ${ }^{9}$ are factors that may be related to depression in this age group.

The increase of the elderly population has been expressive in Brazil, with projections for the year 2025 of approximately 32 million elderly people. If left untreated, depression can aggravate and lead to physical illnesses, cognitive alterations, and even lead to death ${ }^{10}$.

Thus, the objective of the present study was to evaluate the prevalence of depressive symptoms and factors associated in the elderly attended in an ambulatory service of a city in the south of Brazil.

\section{MATERIALS AND METHODS}

This cross-sectional study was conducted between August and December of 2016, through a convenience sample of individuals aged 60 years and over, who were attended in the ambulatory service of the Catholic University of Pelotas (UCPel), in the city of Pelotas, Rio Grande do Sul, Brazil. The study was approved by the Research Ethics Committee of the university under the protocol number 1.805.912. All rights of the investigated population were protected. Participants were informed about the characteristics of the study and they signed a consent form.

All the elderly attended in the ambulatory service were eligible. Patients with severely compromised hearing and/or apparent inability to understand or answer questions were excluded.

The sample size was calculated using the OpenEpi 3.01 (http://openepi.com/Menu/OE Menu.htm) tool. Considering the 650 elderly people seen monthly in the UCPel ambulatory, with a prevalence of $20 \%$ of depressive symptoms, 95\% confidence level, and 80\% power, as well as a $10 \%$ addition for possible losses and refusals, the required sample size was 97 . However, because this study was nested in a larger study, the sample size was 312 elderlies. 
Data collection was carried out in the waiting room by a team of 12 students and health professionals previously trained and calibrated. The collected variables were: gender (male/female); age (60 to 70 years, 71 to 80 years, or 81 years and over); living alone (no/yes); practicing physical activity (no/yes); having a professional activity (no/yes); being retired (no/yes); and socioeconomic class (according to the Brazilian Association of Research Companies -ABEP11categorized into three groups: $\mathrm{A}+\mathrm{B}$ (high/middle class); C (lower middle class); D+E (low class) ${ }^{2}$.

Questions regarding eating habits assessed difficulty with keeping meal times, skipping meals, and maintaining food consumption patterns (categorized into three groups: never/sometimes/a lot). Variables about sleep quality (poor/good) and use of sleep medication (never/once or more times per week/daily) were also included.

The prevalence of depressive symptoms among the elderly was verified through the application of the short form (15 items) Geriatric Depression Scale (GDS-15) ${ }^{11}$ originally developed by Sheikh and Yesavag. The scale contains the items most consistently associated with the depression symptomatology and has shown to have adequate diagnostic accuracy, sensitivity, specificity, and reliability. The GDS-15 had been reported to be an excellent public health tool for identifying depression in non-specialized settings, such as general ambulatorial service, given its reduced application time $^{12}$. The scoring system of the GDS- 15 is from 0 to 5 points, indicating a normal psychological status, 6 to 10 points indicating mild depression, and 11 to 15 points indicating severe depression ${ }^{13}$.

To analyze the data, variables were coded and double-typed in the Epi Info ${ }^{\mathrm{TM}}$ program, version 7 (Center for Disease Control and Prevention, Atlanta, USA). Typing inconsistencies were found by comparing the double data entry and the generated data bank was converted to the Stata 12.0 program. Descriptive statistics were used to calculate proportions and 95\% confidence intervals $(95 \% \mathrm{CI})$ for categorical variables, as well as means, range, and standard deviations (SD) for numerical variables. For crude analysis, the chisquare and Pearson's tests were used, considering $p$-values $\leq 0.05$ statistically significant. In the adjusted analysis, Poisson regression with robust variance was used and the results were reported as prevalence ratios. For statistical modeling, we adopted the strategy of backward selection with the inclusion of all sociodemographic variables. In addition, we adopted a critical level of $p \leq 0.20$ for permanence in the model. The data were expressed as odds ratios (OR) and confidence intervals of 95\% (95\% CI).

\section{RESULTS}

A total of 312 elderly people were interviewed, and a $30.5 \%$ prevalence of depressive symptoms was observed. A higher prevalence of depressive symptoms was found among women (35.9\%), in individuals aged over 81 years $(33.3 \%)$, belonging to the low class (30.8\%), living alone $(40.3 \%)$, physically inactive $(36.5 \%)$, who did not perform professional activities (36.5\%), and retirees (31.4\%). These elderlies presented difficulties in maintaining meal schedules (63.6\%), not skipping meals (52.6\%), and having a regular food consumption pattern $(66.7 \%)$. Considering sleep aspects of the participants affected by depressive symptoms, $56.9 \%$ presented poor sleep quality and $45.3 \%$ took daily sleep medication (Table 1 ).

Table 1. Sample characteristics and their association with depression in elderly. Pelotas, RS, 2018.

\begin{tabular}{|c|c|c|c|}
\hline Variables & $\mathbf{N}(\%)$ & $\begin{array}{c}\text { Without } \\
\text { depression } \\
\text { N (\%) }\end{array}$ & $\begin{array}{c}\text { With } \\
\text { depression } \\
\text { N }(\%)\end{array}$ \\
\hline \multicolumn{4}{|l|}{ Gender } \\
\hline Male & $131(42.0)$ & $101(77.1)$ & $30(22.9)$ \\
\hline Female & $181(58.0)$ & $116(64.1)$ & $65(35.9)$ \\
\hline \multicolumn{4}{|l|}{ Age } \\
\hline 60 to 70 years & $191(61.2)$ & $135(70.7)$ & $56(29.3)$ \\
\hline 71 to 80 years & $97(31.1)$ & $66(68.0)$ & $31(32.0)$ \\
\hline 81 years and over & $24(7.7)$ & $16(66.7)$ & $8(33.3)$ \\
\hline \multicolumn{4}{|l|}{ Socioeconomic class } \\
\hline High class & $25(8.0)$ & $18(72.0)$ & $7(28.0)$ \\
\hline Middle class & $76(24.4)$ & $53(69.7)$ & $23(30.3)$ \\
\hline Low class & $211(67.6)$ & $146(69.2)$ & $65(30.8)$ \\
\hline \multicolumn{4}{|l|}{ Live alone } \\
\hline No & $250(80.1)$ & $180(72.0)$ & $70(28.0)$ \\
\hline Yes & $62(19.9)$ & $37(59.7)$ & $25(40.3)$ \\
\hline \multicolumn{4}{|l|}{ Practices physical activity* } \\
\hline No & $200(64.3)$ & $127(63.5)$ & $73(36.5)$ \\
\hline Yes & $111(35.7)$ & $89(80.2)$ & $22(19.8)$ \\
\hline \multicolumn{4}{|l|}{ Perform professional activity* } \\
\hline No & $253(81.4)$ & $170(67.2)$ & $83(32.8)$ \\
\hline Yes & $58(18.6)$ & $46(79.3)$ & $12(20.7)$ \\
\hline \multicolumn{4}{|l|}{ Retired* } \\
\hline No & $53(17.0)$ & 39 (73.6) & $14(26.4)$ \\
\hline Yes & $258(83.0)$ & $177(68.6)$ & $81(31.4)$ \\
\hline \multicolumn{4}{|c|}{ Difficulties in keeping meal times* } \\
\hline Never & $265(85.2)$ & $189(71.3)$ & $76(28.7)$ \\
\hline Sometimes & 35 (11.3) & $23(65.7)$ & $12(34.3)$ \\
\hline Often & $11(3.5)$ & $4(36.4)$ & $7(63.6)$ \\
\hline \multicolumn{4}{|l|}{ Difficulties in not skipping meals* } \\
\hline Never & $255(82.0)$ & $186(72.9)$ & $69(27.1)$ \\
\hline Sometimes & 37 (11.9) & $21(56.8)$ & $16(43.2)$ \\
\hline Often & $19(6.1)$ & $9(47.4)$ & $10(52.6)$ \\
\hline \multicolumn{4}{|c|}{ Difficulties maintaining food consumption patterns* } \\
\hline Never & $242(77.8)$ & $175(72.3)$ & $67(27.7)$ \\
\hline Sometimes & 48 (15.4) & $34(70.8)$ & $14(29.2)$ \\
\hline Often & $21(6.8)$ & $7(33.3)$ & $14(66.7)$ \\
\hline \multicolumn{4}{|l|}{ Sleep quality* } \\
\hline Poor & $72(23.2)$ & $31(43.1)$ & $41(56.9)$ \\
\hline Good & $239(76.8)$ & $185(77.4)$ & $54(22.6)$ \\
\hline \multicolumn{4}{|l|}{ Sleep medication } \\
\hline None & $200(64.3)$ & $154(77.0)$ & $46(23.0)$ \\
\hline Once or more times per week & $25(8.0)$ & $15(60.0)$ & $10(40.0)$ \\
\hline Daily & $86(27.7)$ & $47(54.7)$ & $39(45.3)$ \\
\hline Total & $312(100.0)$ & $217(69.5)$ & $95(30.5)$ \\
\hline
\end{tabular}

* 1 lost participant. 
In the crude analysis, the variables associated with the outcome were female sex $(p=0.017)$, living alone $(p=0.049)$, not practicing physical activity $(p=0.004)$, difficulty in keeping meal times $(p=0.006)$, difficulty in maintaining regular food consumption $(p<0.001)$, low quality of sleep $(p<0.001)$, and use of sleep medication $(p<0.001)$.

However, in the adjusted analysis, some variables were statistically associated with the outcome: not practicing physical activity $(p=0.007)$, low sleep quality $(p=0.000)$, and use daily sleep medication $(p=0.001)$. The prevalence of depressive symptoms was 0.58 times
(95\% CI 0.39; 0.86) lower in the elderly who practiced physical activity when compared to those who did not practice. The elderly who took daily sleep medication presented 1.74 (95\% CI $1.23 ; 2.40)$ more odds to develop depression compared to those who did not use medication for sleeping. In addition, the adjusted analysis showed that the elderly who reported having a good sleep quality had a lower probability $(\mathrm{PR}=0.95$; $95 \% \mathrm{CI} 0.95,0.60$ ) of presenting the outcome when compared to those who presented poor sleep quality (Table 2).

Table 2. Multivariate analysis of the prevalence of depression in the elderly according to the independent variables. Pelotas, RS, 2018.

\begin{tabular}{|c|c|c|c|c|}
\hline Variables & PR $^{\text {b }}$ (IC 95\%) & $p$-value & PR $^{\mathrm{a}}(\mathrm{IC}$ 95\%) & $p$-value \\
\hline $\begin{array}{l}\text { Gender } \\
\text { Male } \\
\text { Female }\end{array}$ & $\begin{array}{c}1.00 \\
1.57(1.08 ; 2.27)\end{array}$ & 0.017 & - & - \\
\hline $\begin{array}{l}\text { Age } \\
60 \text { to } 70 \text { years } \\
71 \text { to } 80 \text { years } \\
81 \text { years and over }\end{array}$ & $\begin{array}{c}1.00 \\
1.09(0.76 ; 1.57) \\
1.14(0.62 ; 2.09)\end{array}$ & 0.850 & - & - \\
\hline $\begin{array}{l}\text { Socioeconomic class } \\
\text { High class } \\
\text { Middle class } \\
\text { Low class }\end{array}$ & $\begin{array}{c}1.00 \\
1.08(0.53 ; 2.21) \\
1.10(0.57 ; 2.13)\end{array}$ & 0.960 & - & - \\
\hline $\begin{array}{l}\text { Live alone } \\
\text { No } \\
\text { Yes }\end{array}$ & $\begin{array}{c}1.00 \\
1.44(1.00 ; 2.07)\end{array}$ & 0.049 & $\begin{array}{c}1.00 \\
1.36(0.96 ; 1.91)\end{array}$ & 0.081 \\
\hline $\begin{array}{l}\text { Practice physical activity } \\
\text { No } \\
\text { Yes }\end{array}$ & $\begin{array}{c}1.00 \\
0.54(0.36 ; 0.82)\end{array}$ & 0.004 & $\begin{array}{c}1.00 \\
0.58(0.39 ; 0.86)\end{array}$ & 0.007 \\
\hline $\begin{array}{l}\text { Perform professional activity } \\
\text { No } \\
\text { Yes }\end{array}$ & $\begin{array}{c}1.00 \\
0.63(0.37 ; 1.08)\end{array}$ & 0.091 & - & - \\
\hline $\begin{array}{l}\text { Retired } \\
\text { No } \\
\text { Yes }\end{array}$ & $\begin{array}{c}1.00 \\
1.19(0.73 ; 1.93)\end{array}$ & 0.485 & - & - \\
\hline $\begin{array}{l}\text { Difficulties in keeping meal times } \\
\text { Never } \\
\text { Sometimes } \\
\text { Often }\end{array}$ & $\begin{array}{c}1.00 \\
1.20(0.73 ; 1.97) \\
2.22(1.37 ; 3.61)\end{array}$ & 0.006 & $\begin{array}{c}1.00 \\
1.30(0.82 ; 2.05) \\
1.61(0.91 ; 2.86)\end{array}$ & $\begin{array}{l}0.264 \\
0.103\end{array}$ \\
\hline $\begin{array}{l}\text { Difficulties in not skipping meals } \\
\text { Never } \\
\text { Sometimes } \\
\text { Often }\end{array}$ & $\begin{array}{c}1.00 \\
1.60(1.05 ; 2.44) \\
1.95(1.21 ; 3.12)\end{array}$ & 0.006 & - & - \\
\hline $\begin{array}{l}\text { Difficulties maintaining food consumption patterns } \\
\text { Never } \\
\text { Sometimes } \\
\text { Often }\end{array}$ & $\begin{array}{c}1.00 \\
1.05(0.65 ; 1.71) \\
2.41(1.67 ; 3.47)\end{array}$ & $<0.001$ & $\begin{array}{c}1.00 \\
0.72(0.44 ; 1.20) \\
1.35(0.86 ; 2.09)\end{array}$ & $\begin{array}{l}0.208 \\
0.189\end{array}$ \\
\hline $\begin{array}{l}\text { Sleep quality } \\
\text { Poor } \\
\text { Good }\end{array}$ & $\begin{array}{c}1.00 \\
0.38(0.23 ; 0.63)\end{array}$ & $<0.001$ & $\begin{array}{c}1.00 \\
0.44(0.32 ; 0.60)\end{array}$ & 0.000 \\
\hline $\begin{array}{l}\text { Sleep medication } \\
\text { None } \\
\text { Once or more times per week } \\
\text { Daily }\end{array}$ & $\begin{array}{c}1.00 \\
1.74(1.01 ; 3.00) \\
1.97(1.40 ; 2.78)\end{array}$ & $<0.001$ & $\begin{array}{c}1.00 \\
1.53(0.97 ; 2.42) \\
1.72(1.23 ; 2.40)\end{array}$ & $\begin{array}{l}0.067 \\
0.001\end{array}$ \\
\hline
\end{tabular}

a Adjusted prevalence ratio.

b Crude prevalence ratio. 


\section{DISCUSSION}

This study aimed to evaluate the prevalence of and factors associated with depressive symptoms in the elderly. Among the elderly attended in an ambulatorial service of the city of Pelotas, a prevalence of over $30 \%$ of depressive symptoms was found. It is worth mentioning that the prevalence of this disease in old age is discrepant and can vary between 13 and $39 \%{ }^{14}$. However, this variability might be explained by the use of different methodologies for the investigation of the disease and geographical characteristics of the sample ${ }^{15}$.

Our study has revealed results that refute wellestablished gender roles in society that preconize that males are more affected by physical impairment, while the females are more affected by psychological and psychiatric disorders. Also, our findings demystify the idea that men and women have a different view of healthcare and use health services differently. Thus, in contradiction to the literature, gender was not associated with depression in our study. From this perspective, gender differences among the elderly seem to be dissipating. Accordingly, in the last decade, some studies have proposed that the absence of significant differences between men and women in the prevalence of depression is due to the cultural evolution of female valorization ${ }^{16}$.

It is known that the quantity of required sleep for the elderly population is substantially lower compared to other age groups ${ }^{17}$. However, the quality of sleep is fundamental, being considered a factor of health and quality of life ${ }^{18}$. Currently, it is well established in the literature that poor sleep quality is a frequent complaint of a considerable proportion of elderly individuals with depression ${ }^{19,20,21}$. In this context, the results evidenced through this study reveal that elderly that considered their sleep quality as good presented a lower prevalence of depressive symptoms, confirming that this issue is essential particularly for mental health and that it ensures normal cognitive abilities ${ }^{22}$.

Sedentary participants presented a higher prevalence of depressive symptoms even after adjusted analysis, corroborating systematic reviews that show a positive association between physical activity and mental health $23,24,25,26$. The literature suggests that active individuals have a greater capacity for social interaction, improved $\operatorname{mood}^{27}$ and cognitive ability ${ }^{28}$, as well as less susceptibility to stress ${ }^{29,30}$, thus being less likely to present depressive signs and symptoms. During physical exercise a number of changes in neuroendocrine mechanisms, such as increased secretion of serotonin and endorphin, occur ${ }^{31}$. Thus, the practice of physical activities among the elderly can be considered a factor that contributes to the treatment of depressive symptoms, as supported by biological parameters ${ }^{25,32}$.

A higher prevalence of depressive symptoms was found among participants who reported poor sleep quality and the use of daily sleep medication. The literature shows that these variables have an intimate relationship with each other and with depression in the elderly ${ }^{33}$. In this context, the quality of sleep can be improved with continued and daily use of selective serotonin reuptake inhibitors. The use of this type of medication, however, should be considered with caution due to the numerous adverse effects ${ }^{34}$, such as drowsiness, dizziness, memory loss, lethargy, and lack of concentration. The administration of these drugs requires moderation since their chronic use has been associated with higher mortality. In addition, recent research suggests that the risks of these drugs may be potentiated in the elderly ${ }^{35}$. Therefore, the literature as suggested that the practice of physical activities can be an alternative treatment for depression and insomnia, being at the same time a safe, healthy, and cheap measure ${ }^{36,37}$.

The results of this study should be analyzed with caution since convenience samples provide results with reduced generalizability due to the low statistical rigor $^{38}$. In addition, as a cross-sectional study, the possibility of a reverse causality bias does not allow the establishment of a temporal relationship between exposure and outcome ${ }^{39}$.

This study highlights the importance of investigating depressive symptoms among the elderly. Depressive symptoms, which has a direct impact on the quality of life in the general population, is aggravated by the natural vulnerability of the old age. Moreover, this study allowed the identification of characteristics that are associated with depressive symptoms, which can assist in the elaboration of public policies directed to this age group for the prevention or improvement of the disorder. Finally, more population-based studies with the elderly should be done with the focus not only on the identification of factors associated with depression but also on characteristics present before the onset of the disorder.

\section{REFERENCES}

1. Aarts N, Zuurbier L, Noordam R, Hofman A, Tiemeier H, Stricker BH, Visser LE. Use of Selective Serotonin Reuptake Inhibitors and Sleep Quality: A PopulationBased Study. J Clin Sleep Med. 2016;12(7):989-95. https://doi.org/10.5664/jcsm.5932

2. ABEP - Associação Brasileira de Empresas de Pesquisa. 2016. Available from: http://www.abep.org/criterio-brasil. [cited 2016 Nov 11, 21:56] . https://doi.org/10.1590/S0004282X1999000300013 
3. Almeida OP, Almeida SA. Confiabilidade da versão brasileira da Escala de Depressão em Geriatria (GDS) versão reduzida. Arq Neuro-Psiquiatr. 1999;57(2B): 421-426.

4. Ancoli-Israel S. Sleep problems in older adults: Putting myths to bed. Geriatrics. 1997;52 (1):20-30.

5. Barcelos-Ferreira R, Izbicki R, Steffens DC, Bottino CMC. Depressive morbidity and gender in community-dwelling Brazilian elderly: systematic review and meta-analysis. Int Psychogeriatr. 2010;22(5):712-26. https://doi.org/10.1017/ S1041610210000463

6. Becker NB, Jesus SN, João KADR, Viseu JN, Martins RIS. Depression and sleep quality in older adults: a metaanalysis. Psychol Health Med. 2016;22(8)889-95. https://doi.org/10.1080/13548506.2016.1274042

7. Blackwell T, Yaffe K, Ancoli-Israel S, Schneider JL, Cauley JA, Hillier TA, et al. Poor sleep is associated with impaired cognitive function in older women: the study of osteoporotic fractures. J Gerontol A Biol Sci Med Sci. 2006;61 (4):405-410. https://doi.org/10.1093/ gerona/61.4.405

8. Campos ACV, Cordeiro EC, Rezende GP, Vargas AMD, Ferreira EF. Qualidade de Vida de idosos praticantes de atividade física no contexto da estratégia saúde da família. Texto Contexto Enferm. 2014;23(4):889-97. https://doi. org/10.1590/0104-07072014002060013

9. D'Avila OP, Wendland E, Hilgert JB, Padilha DMP, Hugo FN. Association between Root Caries and Depressive Symptoms among Elders in Carlos Barbosa, RS, Brazil. Braz Dent J. 2017;28(2):234-40. https://doi. org/10.1590/0103-6440201700933

10. Dunn AL, Trivedi MH, O Neal HA. Physical activity dose-response effects on outcomes of depression and anxiety. Med Sci Sports Exerc. 2001;33(6):587-97. https://doi.org/10.1097/00005768-200106001-00027

11. Gazalle FK, Lima MS, Tavares BF, Hallal PC. Sintomas depressivos e fatores associados em população idosa no Sul do Brasil. Rev Saúde Pública. 2004;38(3): 365-71. https://doi.org/10.1590/S0034-89102004000300005

12. Gnanavel S, Robert RS. Diagnostic and statistical manual of mental disorders, fifth edition, and the impact of events scale-revised. Chest. 2013;144(6):1974. https://doi. org/10.1378/chest.13-1691

13. Gonzalez ACT, Ignácio ZM, Jornada LK, Réus GZ, Abelaira HM, Santos MAB, Ceretta LB, Quevedo JL. Transtornos depressivos e algumas comorbidades em idosos: um estudo de base populacional. Rev Bras Geriatra Gerontol. 2016;19(1):95-103.

14. Guimarães JMN, Caldas CP. The influence of exercise on depressive disorders of the elderly: a systematic review. Rev Bras Epidemiol. 2006;9(4):481-92. https://doi. org/10.1590/S1415-790X2006000400009

15. Hellwig N, Munhoz TN, Tomasi E. Depressive symptoms among the elderly: a cross-sectional population-based study. Ciênc. Saúde Coletiva . 2016;21(11):3575-84 https://doi.org/10.1590/1413-812320152111.19552015
16. Jager J, Putnick DL, Bornstein MH. More than Just Convenient: The Scientific Merits of Homogeneous Convenience Samples. Monogr Soc Res Child Dev. 2017;82(2):13-30. https://doi.org/10.1111/mono. 12296

17. Kripke DF. Chronic hypnotic use: deadly risks, doubtful benefit. Sleep Med Rev. 2000;4(1):5-20. https://doi. org/10.1053/smrv.1999.0076

18. Lucchesi LM, Pradella-Hallinan M, Lucchesi M, Moraes WAS. Sleep in psychiatric disorders. Rev Bras Psiquiatr. 2005;27 (1):27-32. https://doi.org/10.1590/S151644462005000500006

19. McNeil JK, LeBlanc EM, Joyner M. The effect of exercise on depressive symptoms in the moderately depressed elderly. Psychol Aging. 1991;6(3):487-88. https://doi. org/10.1037/0882-7974.6.3.487

20. McPhee JS, French DP, Jackson D, Nazroo J, Pendleton $\mathrm{N}$, Degens $\mathrm{H}$. Physical activity in older age: perspectives for healthy ageing and frailty. Biogerontology. 2016;17(3): 567-80. https://doi.org/10.1007/s10522-016-9641-0

21. Morgan, K. Daytime activity and risk factors for late-life insomnia. J Sleep Res. 2003;12(3):231-38. https://doi. $\operatorname{org} / 10.1046 / j .1365-2869.2003 .00355 . x$

22. Mura G, Carta MG. Physical Activity in Depressed Elderly. A Systematic Review. Clin Pract Epidemiol Ment Health. 2013;12(9):125-35. https://doi. org/10.2174/1745017901309010125

23. Ohida T, Kamal AM, Uchiyama M, Kim K, Takemura $\mathrm{S}$, Sone T, Ishii T. The influence of lifestyle and health status factors on sleep loss among the Japanese general population. Sleep. 2001;24(3):333-38. https://doi. org/10.1093/sleep/24.3.333

24. Oliveira AC, Oliveira NMD, Arantes PMM, Alencar MA. Quality of life in elderly people who practice physical activity - A systematic review. Rev Bras Geriatr Gerontol. 2010;13(2):301-12. https://doi.org/10.1590/S1809. 98232010000200014

25. Paradela EMP, Lourenco RA, Veras RP. Validação da escala de depressão geriátrica em um ambulatório geral. Rev. Saúde Pública. 2005;39(6):918-23. https://doi. org/10.1590/S0034-89102005000600008

26. Paradela EMP. Depressão em idosos. Rev Hosp Univ Pedro Ernesto. 2011;10(2):31-40.

27. Price SD, Holman CD, Sanfilippo FM, Emery JD. Impact of specific Beers Criteria medications on associations between drug exposure and unplanned hospitalisation in elderly patients taking high-risk drugs: a case-timecontrol study in Western Australia. Drugs Aging. 2014; 31(4): 311-25. https://doi.org/10.1007/s40266-014$0164-6$

28. Ramos GCF, Carneiro JA, Barbosa ATF, Mendonça JMG, Caldeira AP. Prevalence of depressive symptoms and associated factors among elderly in northern Minas Gerais: a population-based study. J Bras Psiquiatr. 2015; 64(2):122-31. https://doi.org/10.1590/0047-2085000 000067 
29. Salmon P. Effects of physical exercise on anxiety, depression, and sensitivity to stress: a unifying theory. Clin Psychol Rev. 2001;21(1):33-61. https://doi.org/10.1016/ S0272-7358(99)00032-X

30. Schuch FB, Vancampfort D, Richards J, Rosenbaum S, Ward PB, Stubbs B. Exercise as a treatment for depression: A meta-analysis adjusting for publication bias. J Psychiatr Res. 2016;77:42-51. https://doi.org/10.1016/ j.jpsychires.2016.02.023

31. Sharar E, Sharar DJ. Causal diagrams and the crosssectional study. Clin Epidemiol. 2013;5:57-65. https://doi. org/10.2147/CLEP.S42843

32. Sheikh JI, Yesavage JA. Geriatric depression scale (GDS): recent evidence and development of a shorter version. Clin Gerontol. 19865(1-2):165-73. https://doi.org/10.1300/ J018v05n01_09

33. Sierra JC, Jiménez-Navarro C, Martín-Ortiz J. Calidad del sueño en estudiantes universitarios: importancia de la higiene del sueño. Salud Mental. 2002;25(6):35-43.

34. Street G, James R, Cutt H. The relationship between organised physical recreation and mental health. Health Promot J Austr. 2007;18(3):236-39. https://doi.org/ 10.1071/HE07236

35. Sutoo D, Akiyama K. Regulation of brain function by exercise. Neurobiol Dis. 2003;13(1):1-14. https://doi. org/10.1016/S0969-9961(03)00030-5

36. Téllez A, Juárez-García DM, Jaime-Bernal L, GarcíaCadena C. Prevalencia de transtornos de sueño en relación a factores sociodemográficos y depresión en adultos mayores de Monterrey, México. Rev. Col. Psicol. 2016;25(1):95-106. https://doi.org/10.15446/rcp. v25n1.47859

37. Turkmen K, Erdur FM, Guney I, Gaipov A, Turgut F, Altintepe L, Saglam M, Tonbul HZ, Abdel-Rahman EM. Sleep quality, depression, and quality of life in elderly hemodialysis patients. Int J Nephrol Renovasc Dis. 2012;5:135-42. doi: 10.2147/IJNRD.S36493. https://doi. org/10.2147/IJNRD.S36493

38. Van de Velde S, Bracke P, Levecque K. Gender differences in depression in 23 European countries. Cross-national variation in the gender gap in depression. Soc Sci Med. 2010;71(2):305-13. https://doi.org/10.1016/j. socscimed.2010.03.035

39. Weissman MM, Klerman GL. Sex diferences and the epidemiology of depression. Arch Gen Psychiatry. 1977;34(1):98-111. https://doi.org/10.1001/ archpsyc.1977.01770130100011

\section{AUTHORS:}

REGIANE DA SILVA HEIDEMANN

Programa de Pós-Graduação em Saúde e Comportamento, Universidade Católica de Pelotas (UCPel), Pelotas, Rio Grande do Sul, Brazil.

E-mail: regianegoiania@hotmail.com

Orcid: https://orcid.org/0000-0003-1 158-9300

LUZIANE FONSECA VILELA

Programa de Pós-Graduação em Saúde e Comportamento, Universidade Católica de Pelotas (UCPel), Pelotas, Rio Grande do Sul, Brazil.

E-mail: luziane8@hotmail.com

Orcid: https://orcid.org/0000-0001-6842-254X
GABRIELA KURZ DA CUNHA

Programa de Pós-Graduação em Saúde e Comportamento, Universidade Católica de Pelotas (UCPel), Pelotas, Rio Grande do Sul, Brazil.

E-mail: gabriellakcunha@hotmail.com

Orcid: https://orcid.org/0000-0002-0573-405X

RENAN GARCIA CALDAS

Programa de Pós-Graduação em Saúde e Comportamento, Universidade Católica de Pelotas (UCPel), Pelotas, Rio Grande do Sul, Brazil.

E-mail: renan caldass@yahoo.com.br

Orcid: https://orcid.org/0000-0002-2717-2545

PÂMELA SILVA VITÓRIA SALERNO

Programa de Pós-Graduação em Saúde e Comportamento, Universidade Católica de Pelotas (UCPel), Pelotas, Rio Grande do Sul, Braszil.

E-mail: pamelasvitoria@yahoo.com.br

Orcid: https://orcid.org/0000-0002-4152-5626

ISABEL CLASEN LORENZET

Programa de Pós-Graduação em Saúde e Comportamento, Universidade Católica de Pelotas (UCPel), Pelotas, Rio Grande do Sul, Brazil.

E-mail: isabellorenzet@yahoo.com.br

Orcid: https://orcid.org/0000-0003-1481-1253

Camila Perelló Ferrúa

Programa de Pós-Graduação em Saúde e Comportamento, Universidade Católica de Pelotas (UCPel), Pelotas, Rio Grande do Sul, Brazil.

E-mail: camila_perello@hotmail.com

Orcid: https://orcid.org/0000-0001-8071-377X

MARIANA BONATI DE MATOS

Programa de Pós-Graduação em Saúde e Comportamento, Universidade Católica de Pelotas (UCPel), Pelotas, Rio Grande do Sul, Brazil.

E-mail: marianabonatidematos@gmail.com

Orcid: https://orcid.org/0000-0003-1196-7228

GABRIELE CORDENONZI GHISLENI

Programa de Pós-Graduação em Saúde e Comportamento, Universidade Católica de Pelotas (UCPel), Pelotas, Rio Grande do Sul, Brazil.

E-mail: gabriele.ghisleni@ucpel.edu.br

Orcid: https://orcid.org/0000-0002-1764-6882

RaChel KROLOW SANTOS Silva Bast

Instituto de Ciências Básicas da Saúde, Departamento de Bioquímica, Universidade Federal do Rio Grande do Sul (UFRGS), Porto Alegre, Rio Grande do Sul, Brazil.

E-mail: krolowrachel@yahoo.com.b

Orcid: https://orcid.org/0000-0001-6217-1647

Fernanda Nedel

Programa de Pós-Graduação em Saúde e Comportamento, Universidade Católica de Pelotas (UCPel), Pelotas, Rio Grande do Sul, Brazil.

E-mail:fernanda.nedel@gmail.com

Orcid: https://orcid.org/0000-0002-9055-8328 